\title{
Education program for photonics professionals
}

\section{Melanie Campbell, Donna Strickland}

Melanie Campbell, Donna Strickland, "Education program for photonics professionals," Proc. SPIE 9664, Ninth International Topical Meeting on Education and Training in Optics and Photonics, 966410 (24 October 2005); doi: $10.1117 / 12.2207718$

SPIE Event: Ninth International Topical Meeting on Education and Training in Optics and Photonics, 2005, Marseille, France 


\title{
Ref ETOP057
}

\section{Education Program for Photonics Professionals}

\author{
Melanie Campbell \& Donna Strickland
}

\begin{abstract}
The University of Waterloo, partnered with key industry players, Photonics Research Ontario and the Ontario government, launched Ontario's first diploma-level photonics program to re-skill scientists and engineers. The Education Program for Photonics Professionals (EP3) offers the basics of a university level Optics education. The next step is to provide the courses at distance.

\section{Summary}

The University of Waterloo introduced the Education Program for Photonics Professionals, or EP3 in 2002. The curriculum of EP3 is driven by a broad-based analysis of industry's needs, and tailored with the support of EP3's Industrial Advisory Board. Currently, EP3 is a series of six courses; Introduction to Optics, Physical Optics, Optical Design, Radiometry and Photometry, Lasers and Electro-optics and Optical Communications. Each course is eight weeks long, consisting of 3 lecture hours per week along with graded homework assignments. The students participate in a three-hour lab session during the ninth week of the course. Each course has a mandatory, proctored final examination; students must receive a minimum mark on the examination to pass the course. Students successfully completing each course will receive a certificate; students successfully completing all six courses will receive a diploma from the Faculty of Science of the University of Waterloo.

EP3 has received critical funding from the Ontario government's Ministry of Enterprise, Opportunity and Innovation (MEOI) to develop the courses and laboratories, along with other start-up costs. A number of local industries are supporting the program both through participation in our Industrial Advisory Board and donations of equipment. Also we received large equipment donations through our membership in, Ontario Photonics Education and Training Association (OPETA).

Our first cohort received their diplomas May 2004. The next step is to reach a wider audience. We are considering the different options of real time video link over the web or a self-paced option through distribution of CD-ROMs. The challenge in offering optics courses at a distance is the hands-on component of our courses. Almost every class includes a demonstration. Our presentation will discuss our efforts in transforming our in-class offerings into high-level distance education courses.
\end{abstract}

